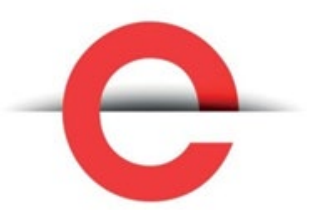

U T S

e P R E S S
Cosmopolitan

Civil Societies: an

Interdisciplinary

Journal

Vol. 11, No. 2

2019

C 2019 by the author(s). This is an Open Access article distributed under the terms of the Creative Commons Attribution 4.0 International (CC BY 4.0) License (https:// creativecommons.org/licenses/ by/4.0/), allowing third parties to copy and redistribute the material in any medium or format and to remix, transform, and build upon the material for any purpose, even

commercially, provided the original work is properly cited and states its license.

Citation: Brown, C. 2019. Resisting the Far-Right: Indigenous Perspectives, Community Arts and StoryBased Strategy. Cosmopolitan Civil Societies: an

Interdisciplinary

Journal, 11:2, 55-73.

https://doi.org/10.5130/ccs.v11.i 2.6765

ISSN 1837-5391 | Published by UTS ePRESS | https://mcs. epress.lib.uts.edu.au
REFEREED PAPER

\section{Resisting the Far-Right: Indigenous Perspectives, Community Arts and Story- Based Strategy}

\author{
Chris D. Brown
}

Centre for Social Impact, Swinburne University of Technology, Australia

Corresponding author: Chris D. Brown, Centre for Social Impact Swinburne, Level 2, AGSE Building, Cnr John and Wakefield Streets, Hawthorn, Victoria, 3122, Australia. cdbrown@swin.edu.au

DOI: http://dx.doi.org/10.5130/ccs.v11i2.6765

Article History: Received 12/09//2019; Revised 14/11/2019; Accepted 03/12/2019; Published 19/12/19

\begin{abstract}
This article explores how we might resist anti-immigration and anti-refugee politics by addressing the socio-historical wellspring from which they emerge and take sustenance. In doing this, I draw upon the concept of story-based strategy and the idea that our potential to address this issue relies on our capacity to fundamentally shift the dominant ways in which people understand and engage with it. This discussion occurs with reference to one practical application of story-based strategy - a community-arts project titled Stories of Hope and Migration - which attempted to re-frame the migration and refugee debate in Australia by funnelling it through a localised Indigenous perspective. In so doing, this article challenges the way in which early British migrants and their descendants have continually excised themselves from the rhetoric of migration. Furthermore, it suggests that through a more nuanced conversation regarding the migration stories of all non-Aboriginal people, we might better promote a more historically aware, compassionate and inclusive society.
\end{abstract}

\section{Keywords}

Far-right, Story-Based Strategy, Indigenous Perspectives, Community Arts

DECLARATION OF CONFLICTING INTEREST The author(s) declared no potential conflicts of interest with respect to the research, authorship, and/or publication of this article. FUNDING The Stories of Hope and Migration project was carried out by Yarkuwa Indigenous Knowledge Centre and was funded by Arts NSW and Multicultural NSW. 



\section{Introduction}

Anti-immigration and anti-refugee sentiment have long been a potent force in Australian politics. Crucially, though, one of the most striking aspects of the overall migration and refugee debate in Australia is its disconnection from Indigenous perspectives - as if the migration issue, and the dominant claims made by white Australian political elites, can and should be made without reference to Indigenous histories and experiences. In response, this article explores how we might resist and confront such damaging and discriminatory politics by addressing the social and historical wellspring from which they emerge and take sustenance. In doing so, I draw upon the concept of story-based strategy and the idea that our potential to address this issue relies on our capacity to fundamentally shift the dominant ways in which people understand and engage with it.

With reference to one practical application of story-based strategy - a mixed-genre community-arts project titled Stories of Hope and Migration - this article explores how we might re-frame the migration and refugee debate by funnelling it through a localised Indigenous perspective. This project was carried out by the Aboriginal-owned community development organisation, Yarkuwa Indigenous Knowledge Centre, in the rural town of Deniliquin in south-western New South Wales. As part of the project, Aboriginal people and migrants were interviewed, and archival research was carried out. These research results then formed the basis for a theatre script, which was performed by a group of community volunteers, and generated material for a historical and photographic exhibition, both of which sought to shift some of the dominant understandings and assumptions that undergird the refugee and migration debate in Australia.

This article proceeds by first exploring the idea of narrative power analysis (NPA), the first component of Reinsborough and Canning's story-based strategy. Using the NPA lens, I critically evaluate, using archival material gathered throughout the project, some of the primary stories and assumptions which animate and underpin anti-immigration and antirefugee politics. Following this, I outline Reinsborough and Canning's idea of the battle of the story, where activists concentrate their energies on controlling the broader frame through which people perceive an issue. Subsequently, I discuss the community exhibition and documentary theatre production as practical examples of story-based strategy, and then conclude with some thoughts on its effectiveness as a social change approach.

\section{Narrative Power Analysis}

Many methods have been used to resist the anti-immigration and anti-refugee politics of the far-right in Australia. Importantly, though, there is often a focus on formal and institutional methods. These methods, such as legal attempts to prevent 'hate speech', or parliamentary efforts to bolster the official rights of the marginalised, may well result in some significant gains, but they often overshadow the availability and potential of other grassroots approaches. Moreover, these formal methods, in their focus on laws and policies, are limited in their capacity to meaningfully address the concealed histories and discriminatory attitudes which have continually given rise to anti-immigration sentiment in Australia. 
With this in mind, another method deserving of further attention in resisting the far-right is storytelling. The creative sharing of stories has long been a key plank in the activist repertoire. The power of stories as a social change tool derives from the way in which narratives are able to emotionally engage people in ideas, possibilities and lived experiences beyond their own (Green, Strange and Brock 2002; Mayer 2014). As Solinger, Fox and Irani put it, "storytelling facilitates "thinking freshly" in places where groups are locked (when we're lucky) in verbal wars over political truths' (2008, p. 214).

Amidst the proliferation and popularisation of storytelling, there are numerous works which explore, detail and conceptualise it as a social change tool (Davis 2002; Solinger, Fox and Irani 2008; VanDeCarr 2015; Zingaro 2016; Bell 2019). Of particular utility to grassroots groups and activists is the story-based strategy (SBS) framework developed by Patrick Reinsborough and Doyle Canning (2010). This flexible framework is concerned with crafting compelling counter-narratives which work to perturb dominant narratives and the assumptions that underpin them. SBS begins with a process called 'narrative power analysis' (NPA) (2010, pp. 17-40), which asks certain questions: 'Which stories define cultural norms? Where did these stories come from? Whose stories were ignored or erased to create these norms?' (p. 20). By asking these questions, NPA is designed to uncover what Reinsborough and Canning label as the 'dominant culture', described as 'stories that validate ... political agendas' and which have 'become invisible as they are passed from generation to generation - carrying assumptions that become "conventional wisdom"” (p. 20). And it is an important process because, in identifying these dominant myths and assumptions, activists are better placed to counter them.

In 2011, the local Deniliquin Paper, the Pastoral Times, published a near full page letter to the editor - headlined 'Silent Feet' - which captured some of the key narratives that the Stories of Hope and Migration project sought to confront. The letter argued that 'we have a different set of values and respect for life to those who come here to disrupt our way of life and daily routine' (Trist 2011, p. 9). Furthermore it argued that:

Those who are responsible for terrorism are well settled in the community, but they have not assimilated into our way of life and are unlikely to do so at any time in the future. In time they will want to build more mosques and will want their children educated in Muslim schools...Those who have a criminal background are prepared to wait patiently in the shadows while they meticulously plan acts of terrorism aimed at inflicting maximum casualties against the country that provides them with welfare, housing and an income to support their families; without ever giving anything back (p.9)

The letter concluded by imploring everyone to 'fly the Australian flag at your home. Continue to support Australia Day ... Protest loudly when minority groups want to change our culture to suit theirs ... (and) instill into the younger generation the values and pride in being a fair dinkum Aussie and the reasons we need to retain our own identity' (p. 9).

This letter to the editor, printed in a small rural newspaper, is, of course, a localised expression of the anti-immigration, anti-refugee and anti-Muslim rhetoric that had, by 2011 
when it was published, long characterised Australian politics. In the sections below, I identify and challenge three particular assumptions which undergird these kinds of arguments. The analysis is not intended to be extensive, but rather, seeks to highlight the initial process of narrative power analysis that helped to generate and inform the community arts project which was to follow.

\section{British Migrants?}

Australia is commonly considered an immigration nation. What is interesting about this, though, is to whom the term migrant usually refers. People with Chinese, Italian or Lebanese heritage, for example, are often ascribed as migrants in the Australian context. At the same time, however, we rarely describe or depict people of British heritage as descendants of migrants. Indeed, white Australia has, by and large, managed to distance itself from the concept - as if the term migrant does not really apply to the white Australian experience.

This short-sighted and ahistorical perception of Australia's migration history has long been a feature of the dominant white-Australian mindset. Beginning with the arrival of the first colonists, British migrants moved rapidly to establish a hierarchy which wedged, elevated and distinguished themselves above those who were here before them, and those who sought to come after them. We have, in the rural town of Deniliquin, a rather vivid documentation of this process. In 1882, the Pastoral Times printed an article entitled Reminiscences of Old Deniliquin which captured the way in which the local Aboriginal people were viewed and treated in the mid-nineteenth century:

The snuff of a candle and the life of a blackfellow were of about equal importance, and the law upon the matter was so beautifully ineffective that wholesale massacres passed off then with as little comment as a kangaroo battle or wallaby drive does now. At Perricoota the manager had by some means become possessed of a small cannon, and with that implement of destruction he used to practice upon the aboriginals on high days and holidays. There are yet several living in the district who can recollect Jimmy Maiden's cannon, and who used to envy the owner of such a useful implement of warfare in those exciting times (Pastoral Times 1882).

As this snippet suggests, the new settlers were ruthless in their opposition to continued Aboriginal presence in the region. Crucially, though, this violent claim to the land was rarely seen as an unjust or brutal imposition by newly arrived migrants. Rather, it was viewed as an assumed right or privilege, simply because those doing the claiming had deemed the land legally unoccupied, or terra nullius.

In assuming this right to the land, early European settlers were equally ruthless in protecting it from a subsequent wave of Chinese migration. In 1878, the Pastoral Times published the following on what they called 'the Asiatic race':

It is hardly conceivable that an English woman would be so lost, as to debase herself by a union with a Chinese. A regard for the future of our race condemns such a course. How can we bear to think of our children's hair being blackened, their eyes elongated, their noses flattened, their fair complexions yellowed? And 
the mind, doubtless, degraded in the same degree as the body (Pastoral Times 1878).

This British disdain towards Chinese migrants, their economic ambitions, and their cultural differences, was enacted with minimal or no reflection upon the British migration experience, and the way in which they had, and continued to impose, violently, their own culture and economic agenda upon those who were here before them.

In more recent times, this dominant pattern of thinking regarding migration has been reinforced by political elites. Former Prime Minister (2013-2015), Tony Abbott, who was appointed the Special Envoy for Indigenous Affairs after he was deposed as leader of the Liberal Party, said the following in relation to the first fleet's landing:

As we look around this glorious city of Sydney, as we see the extraordinary development, it's hard to think that back in 1788 it was nothing but bush. The marines and the convicts and the sailors that straggled off those 12 ships, just a few hundred yards from where we are now, must have thought they had come almost to the moon ... Everything would have seemed so extraordinarily basic and raw, and now a city which is one of the most spectacular cities on our globe (in Henderson 2014).

And in 2014, whilst launching the 100 Defining Moments in Australian History project, Abbott argued that 'the arrival of the First Fleet was the defining moment in the history of this continent. Let me repeat that, it was the defining moment in the history of this continent. It was the moment this continent became part of the modern world' (in Dingle, 2014).

Abbott describes European migration to Australia - via boats - as a magnificent historical occasion and achievement which overcame, modernised and civilised what he describes as nothing but a basic raw environment of bush. And yet, at the same time, some Australian political elites are openly questioning the legitimacy of asylum-seekers, particularly those who arrive by boat. Of course, those crafting and communicating the anti-asylum-seeker narratives pay scant regard to the events of 1788 - that supposedly defining moment in which newcomers first came to these shores - as if they do not count on the migration ledger. Or if they are acknowledged, as in Abbott's comments, it is argued that such a process should be seen only in a positive, modernising and emancipatory light, despite the well-documented brutality and cultural destruction it wrought.

The point here is that colonisation set in train a two-part attitudinal pattern that still dominates today. First, a refusal or disregard for who was on this land before they migrated a process which rapidly enabled European colonisers to think of themselves not as migrants, but as privileged, rightful and benevolent owners of the land. And second, a disdain for anybody who strove to migrate to Australia after - ultimately, a disdain for anyone who tried to do or claim anything that they had already done.

\section{An Enlightened Multicultural Success Story?}

Another dominant narrative which often accompanies anti-immigration and anti-refugee politics is that contemporary Australia represents a multicultural success story. In this 
narrative, proponents tend to ignore the historical snippets of the type highlighted above, drawing attention only to what they see as successful examples of migration, and, accordingly, the generosity and openness of Australians. In Trist's (2011) letter to the Pastoral Times, for example, he writes:

At previous Australia Day ceremonies I have attended, speakers have paid tribute to those migrants who have established their market gardens, and other enterprising business people who have worked extremely hard, often under the most arduous and primitive conditions, seeking to earn a living and raise their families in their new homeland. The Italians, Greeks, Poms and Eastern Europeans have all been great migrants and contributors to this country and have all assimilated well. As a nation we are extremely generous and tolerant. Some would say we are too generous and charity begins at home (p. 9).

Another way in which the multicultural success narrative is framed, often by political elites, is to minimally acknowledge certain aspects of Australia's history on race relations, but then present these aspects as relics of a discredited past - as if we are now a more compassionate, inclusive and enlightened society. Prime Minister Scott Morrison encapsulated this when, talking on the issue of migration, he noted: 'sadly, white supremacy in sections of Australia is not new ... It's been around for well over a century and at one time in Australia's history it could even be argued that it held some sort of mainstream position. Thankfully that's no longer the case' (in SBS News 2019).

The resurgence of many far-right parties and groups in Australia over recent years provides one example which contradicts this comfortable assertion that white supremacy is no longer a mainstream or common position in Australia. When Pauline Hanson, leader of the One Nation party, first came to the Senate in 1996, she warned of the dangers of being 'swamped by Asians' (Hanson, 1996). Two decades later, in a subsequent speech to the Senate, she narrowed her concern, focusing on blocking the entry of Muslims into Australia, and in 2018 put forward a Senate motion that 'it's OK to be white' (in Karp 2018). In the same year, then Senator Fraser Anning voiced support for the White Australia Policy and its reinstatement, and called for a 'final solution' to Muslim immigration (Anning 2018).

These are, of course, the comments of the far-right which have largely been critiqued and disowned by most of the parliament. And yet, whilst mainstream political leaders perform a kind of principled opposition to these ideas, there is little acknowledgement of the way in which anti-boat-people rhetoric, since the Tampa crisis ${ }^{1}$, has laid a conducive foundation for the resurgence of far-right and Islamophobic politics (Aly 2019; Barton 2019). Indeed, one does not have to look too far to find examples which highlight the troubling relationship between mainstream politics and anti-immigration sentiment in Australia. During the 2019 NSW state election, footage was released of the Labor candidate, Michael Daley, who said, in

\footnotetext{
${ }^{1}$ In August 2001, the Liberal government of John Howard refused permission for a Norwegian freighter, MV Tampa, to enter Australian waters after it had rescued over 400 asylum-seekers from a sinking fishing vessel. The ordering of the Australian defence forces to prevent the ship from docking in Christmas Island to discharge its passengers caused a diplomatic incident with the Norwegian government. The incident led to a rise in support for the government's stand against asylum-seekers arriving by sea.
} 
regards to housing affordability, 'our young children will flee and who are they being replaced with? They are being replaced by young people from typically Asia with PhDs' (in Visentin 2019). One year earlier, his predecessor, Luke Foley, used the term 'white flight' to express his concern over western Sydney suburbs such as Fairfield which was experiencing a large influx of Syrian and Iraqi refugees (in Sas and Gerathy 2018). This comment received vocal support from Pauline Hanson who noted that she had 'been saying this for years' (in Sas and Gerathy 2018). Federal Liberal MP Peter Dutton has been vocal in his criticism of 'African gang violence', suggesting that 'people are scared to go out to restaurants of a nighttime because they're followed home by these gangs' (in Hunter and Preiss 2018). And he has accompanied these comments with a call for supporting white farmers from South Africa, arguing that they require support and protection from 'civilised countries' (in The Guardian 2018).

What is interesting, though, is that the strongest proponents of exclusionary politics often lay claim to the multicultural narrative, often using it to rebuke those who accuse them of racism. Far-right groups such as Reclaim Australia, for example, try to combat the racism and antimulticultural critique by highlighting how their movement has members from a diverse range of backgrounds and cultures. John Saffran, in his book on the Australian far-right, notes that the leadership and constituency at certain far-right meetings displayed a cultural diversity that many well-intentioned organisations/groups would envy (Saffran 2017). Most commonly, though, proponents argue that they have no issue with particular races, cultures or religions, but are concerned only with those who, having come to this country, cannot or will not 'integrate'. Trist (2011), in Deniliquin, deploys a quote often attributed to Australia's first Prime Minister, Edmund Barton:

In the first place, we should insist that if the immigrant who comes here in good faith becomes an Australian and assimilates himself to us, he shall be treated on an exact equality with everyone else, for it is an outrage to discriminate against any such man because of creed, or birthplace, or origin. But this is predicated upon the person's becoming in every facet an Australian, and nothing but an Australian. (p. 9).

For Dutton, Africans in general are not a problem, it is just the ones who 'haven't integrated' or are not 'abiding by our laws' or 'don't adhere to our culture' that 'are not welcome here' (in Hunter and Preiss, 2018).

There is a contradiction, of course, between the claim that Australia represents a multicultural success story, and the assumption discussed above that those new migrants arriving on Australia's shores need to 'integrate', else they render themselves unwelcome. One might suggest that the notion of integration does not have to involve the abandoning of cultural difference, and that such cultural diversity can and should sit alongside a genuine integrative engagement with and obedience to local laws, culture, customs and language. Notably, though, this demand foisted upon new migrants that they strike some kind of acceptable and non-threatening (to elites) balance between the maintenance of their culture, on the one hand, and their integration with the dominant society to which they have come, on the other, is one that was never placed upon the early British colonists. They were, it seems, free to intrude, distort and dominate as they saw fit. And the contemporary descendants of this process still, 
by and large, ignore this historical reality, whilst ensnaring new migrants within their own concocted rules. Indeed, when former Prime Minister John Howard infamously argued, at the time of the Tampa affair, that 'we will decide who comes to this country and the circumstances in which they come' (Howard, 2001), it was not part of the national conversation how this self-evident right of current inhabitants was not extended to Aboriginal people at colonisation, and has never been allowed to intrude on white people's privilege.

\section{A Glorious Pioneer or An Illegitimate Economic Migrant?}

Another dominant narrative used to frame asylum-seekers in Australia is one which depicts them as nothing but illegal and unjustified economic migrants. 'Let's just face some facts here', declared previous Prime Minister Kevin Rudd, 'a whole bunch of people who seek to come to this country are economic migrants, who are seeking to comport themselves as refugees' (in Hawley 2013). Similarly, Scott Morrison, when he was Immigration Minister, said of Tamil asylum-seekers that their 'passage to Australia here is nothing more than an economic migration seeking to illegally enter Australia' (in Barlow 2014). The assumption guiding this narrative is that people, having disguised themselves as asylum-seekers, will gain entry into Australia and subsequently soak up the welfare system, or otherwise exploit the economic opportunities they find, much to the detriment of 'our' standard of living.

Research provided by the Refugee Council of Australia (2016) highlights that the claims around economic migration and refugees are spurious. They note that between January 1976 and June 2015, 69,602 asylum seekers arrived by boat. Of these, 37,491 asylum seekers had their claims processed, and $81 \%$ of them were found to be genuine refugees. That is, their decision to travel by boat to Australia had, according to the Australian government's processes, nothing to do with economic motivation, and everything to do with escaping a genuine fear of persecution in their home country.

Beyond the factual inaccuracy of this narrative, however, lies a deeper and pernicious doublestandard. Economic migration, tainted as it is these days, seems only to have taken on this problematic connotation in relation to non-European migrants. Rather than recognise any broader economic disparity and injustice which might underpin migration between countries, those migrating to Australia from poorer countries have routinely been depicted as sneaky, money-hungry people who threaten local jobs and overall standards of living.

In stark contrast, the British early settlers are framed in a rather different light. These settlers, or pioneers as they are often called, often made the decision to migrate to Australia for financial reasons. And on arrival, these settlers ruthlessly sought out lucrative agricultural opportunities that were denied to them in Britain. For this journey of economic adventure, and for the so-called work they did in shaping contemporary Australia, these British economic migrants continue to be glorified, their courage, endeavour and initiative all celebrated as something which has made this country what it is.

In Deniliquin, these celebratory ideas and attitudes regarding the economic migration of British settlers play out in a very striking way. George Peppin, for example, one of the early settlers in the region, made the (economic) decision to migrate to Australia when 'farming 
was at a low ebb in England' (Hone 1974). At the time of his death, Peppin had amassed great wealth and had become well known for the unique breed of sheep he helped develop the Peppin Merino - which was very much considered a key component of the early sheepbased Australian economy. For these economic efforts, Peppin is widely recognised, and his name is given to the local (Peppin) Heritage Centre.

What is significant, though, is the way in which the heritage centre, and Australian political discourse more generally, remains so comfortable in recognising and celebrating the so-called work and legacy of these early economic migrants. For, at the same time, elitist politicians and far-right proponents continue to condemn asylum-seeking as little more than an illdisguised and unjust attempt at improving economic position. This hypocrisy is particularly pertinent when funnelled through an Aboriginal perspective because in Deniliquin, as across all of Australia, there remains a huge disparity between the wealth and well-being of those families who directly descend from these early settlers, and Aboriginal people. British economic migration, whilst framed as a courageous and inspiring tale of hard work and deserved reward, primarily served to secure lives and lifestyles for some, and poverty for others. And crucially, this dominant narrative ignores or distorts this result of British economic migration, and instead spruiks a history of supposed generosity and benevolence from white Australia. So, whilst Trist (2011) confidently asserts that 'we', presumably white Australians, 'have a different set of values and respect for life of those who come here to disrupt our way of life and daily routine' (p. 9), he ignores the 'disruption' caused by settlement, and the ongoing impacts it continues to have on the "way of life and daily routine" of Aboriginal people.

\section{Changing the Frame: Foregrounding Indigenous Perspectives}

Having identified and analysed the dominant narratives and assumptions pertaining to the migration and refugee debate in Australia, the Stories of Hope and Migration project then sought to challenge and re-frame them. This component of story-based strategy is called the battle of the story. In describing this idea, Reinsborough and Canning (2010) contrast it with the 'story of the battle', which they describe as a story-telling approach/tactic that is designed to mobilise supporters 'who already share much of your worldview and core values' (p. 43). The battle of the story, by contrast, operates outside the comfortable circle of core supporters, seeking to persuade others not already bound by similar values or convinced of certain assumptions. As they explain:

the battle of the story is the larger struggle to determine whose stories are told, how they are framed, how widely these stories are heard, and how deeply they impact the dominant discourse. The battle of the story is the effort to communicate the why - the interpretation and relevance of actions and issuesthat helps a social change message reach a broader section of the public. To succeed in changing the dominant culture's framing of an issue, our movements must win the battle of the story.

It is, of course, no small task to try to re-frame what is a damaging and dominant national, indeed global, debate. And whilst this project makes no claim to having succeeded in this 
elusive goal, what it did try to do was to downsize and localise this challenge. To do this, it foregrounded a local Indigenous perspective, prompting people to consider the migration debate, and their own personal histories, not through the lens of the Australian nation, but through the lens of the Wamba Wamba Perrepa Perrepa nation. Below I discuss some of the extracts from the play, as well as the historical and photographic exhibition which accompanied the performance, which highlight this approach.

\section{Historical and Photographic Exhibition}

The exhibition presented various historical documents and photographs in an attempt to productively perturb the kinds of narratives highlighted above. The primary concept behind the exhibition was to capture the many waves of migration that have occurred to Deniliquin, and in particular, to pictorially depict Europeans as one of these many migrating communities, rather than allowing them to remain, as they often are, as some kind of privileged resident that sits outside or beyond the notion of migration. To express this idea, the exhibition began with a collection of local Aboriginal artefacts and cultural works which were designed to highlight long-term Aboriginal presence in the region. These artefacts and cultural works included grinding stones, coolamons and woven baskets, as well as a use and occupancy map of the Werai Forest. In providing these artefacts and cultural works as the first component of the exhibition, our intention was to frame the viewer's experience of the rest of the exhibition through this acknowledgement and celebration of long-term Aboriginal ownership and custodianship.

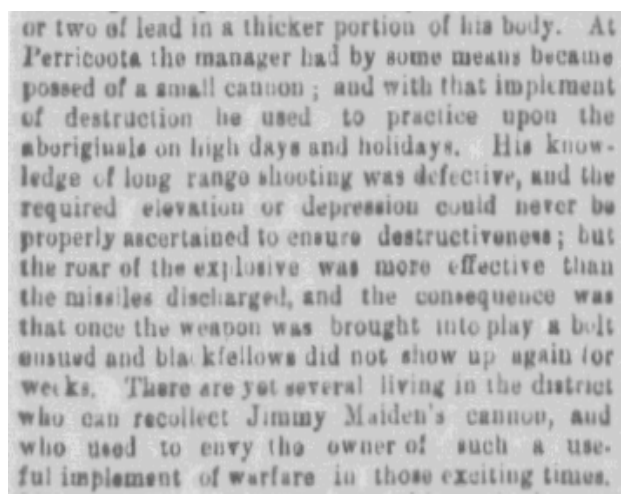

Image 1: Pastoral Times Article

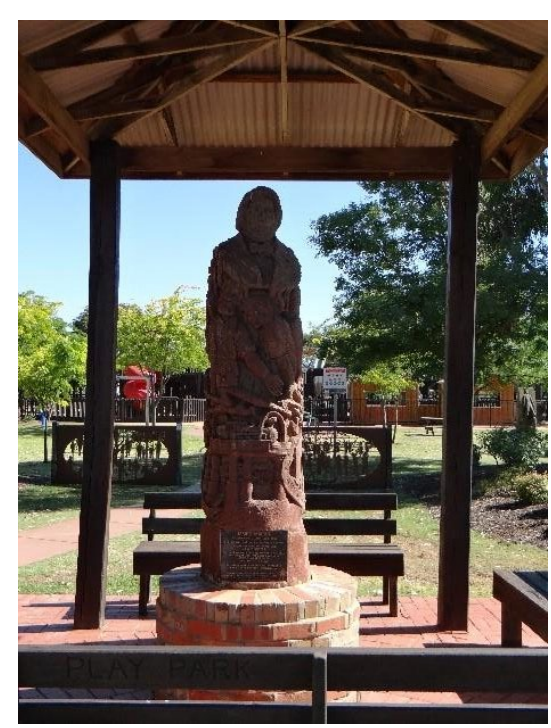

Image 2: James Maiden Statue

The second section of the exhibition introduced that very significant first wave of migration European colonisation. To this end, the exhibition presented the faces of early European settlers in the region, many of whom are well-known in the town, and, as noted above, recognised and celebrated through various public buildings and artworks. Crucially, though, our exhibition framed these migrants, not in the usual romantic and celebratory fashion as brave and industrious pioneers, but as the region's first migrants who, upon arrival, disregarded the culture and presence of the local Aboriginal people. For example, the face of 
the early settler James Maiden was shown alongside a large printed version of the 1882 'Reminiscences of Old Deniliquin' article from the Pastoral Times (see Image 1 above). This is significant because Maiden is known as the founder of Moama (a nearby town) and is recognised through a public sculpture at the local children's park (see Image 2). Importantly, though, Maiden is also the 'Jimmy Maiden' talked of in the article which reports how he, 'on high days and holidays', liked to shoot his cannon at the local Aboriginal people.

In the same section, we displayed a range of images which present not just European migration, but the way in which these migrants dominated, transformed and exploited the local people, land and culture. The exhibition provided sketches from John Phillips, an early squatter in the region, whose artworks of the time, now stored in the State Library of NSW, depict burgeoning homesteads and the unwanted and uncomfortable presence of Aboriginal people on their fringes (see Image $3^{2}$ ). Provided also was an early agricultural map from 1877
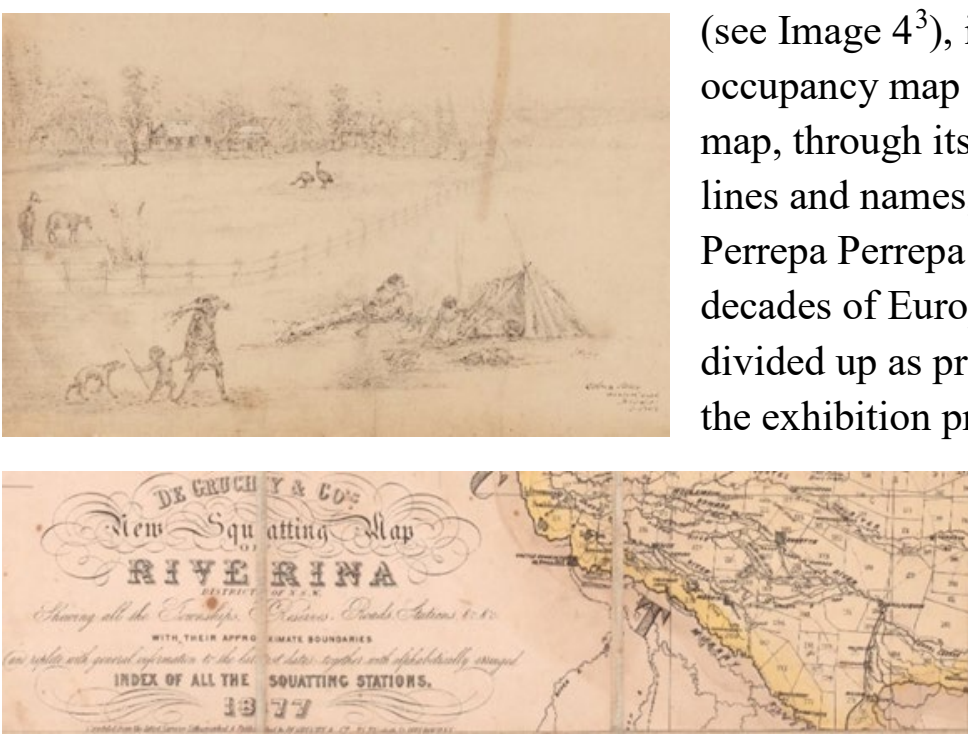

(see Image $4^{3}$ ), intended as a contrast to the use and occupancy map already presented. The agricultural map, through its ever-thickening maze of property lines and names, highlights how Wamba Wamba Perrepa Perrepa Country was, within only a few decades of European migration, bought, sold and divided up as private agricultural plots. In addition, the exhibition provided a photograph which shows a man leaning upon a tree on the riverbank, surrounded by the unique breed of sheep that was developed in the area. Rather than highlighting the development in agriculture, however, this image captures the European overriding of Aboriginal people, for on the tree, against which this settler so proudly leans, is a scar, where bark has been taken from the tree to create most probably a canoe - evidence of long-term Aboriginal presence and use of the land that was now seen by the British as little more than grazing pasture for commercial wool production.

The following section of the exhibition depicted subsequent waves of migration to Deniliquin. In particular, the exhibition provided a number of portraits of Chinese community members who lived and worked in the Deniliquin region from the late 1800 s until the mid1900s. In presenting these images, our intention was to highlight a degree of similarity between the British and Chinese experience of migration in Deniliquin, where people from other places and cultures made a difficult journey in search of greater prosperity. At the same time, the exhibition sought to emphasise an important difference between the power and wealth accumulated by early British migrants, and the discrimination and disdain that was endured by the Chinese. Accompanying the portraits of Chinese community members, for

\footnotetext{
2 Image 3: 'Cobran Station' by John Phillips (courtesy of the State Library of NSW)

${ }^{3}$ Image 4: Squatting Map, 1877 (courtesy of the State Library of NSW)
} 
example, was an 1878 article from the Pastoral Times which wrote the following of the Chinese:

There are a few people who appear to think highly of them in some respects, and endeavour to combat the opinion of their inferiority by pointing out their immense numbers, their love of order, and the length of time that their empire has continued. But such shallow arguments can easily be disposed of. And, flies, and mosquitoes are even more numerous than Chinese, yet no one thinks of comparing them with men. Ants, too, have very much of the same methodical routine in their habits, and seem to thrive as well by it; but we do not compare their instinct with our enlightened reason (Pastoral Times, 1878).

In addition, the exhibition provided an 1897 article from the Pastoral Times which outlined the conditions by which Chinese migrants could enter the colony of New South Wales in the lead up to the white Australia policy:

One Chinese allowed to every 300 tons of registered tonnage of the vessel, but each must pay the poll tax. Master liable to a penalty of $£ 100$ for each in excess of above ... Poll tax of $£ 60$ on each Chinese arriving both by sea and land.

Naturalisation is not allowed on any ground whatever, and on Chinese returning to the colony they come under the provisions of the Act (Pastoral Times, 1897).

In conclusion to the exhibition, the final artwork was a large photograph of a scarred tree in Deniliquin, emblematic, as noted earlier, of Indigenous ownership and presence prior to European migration (see Image $7^{4}$ ).

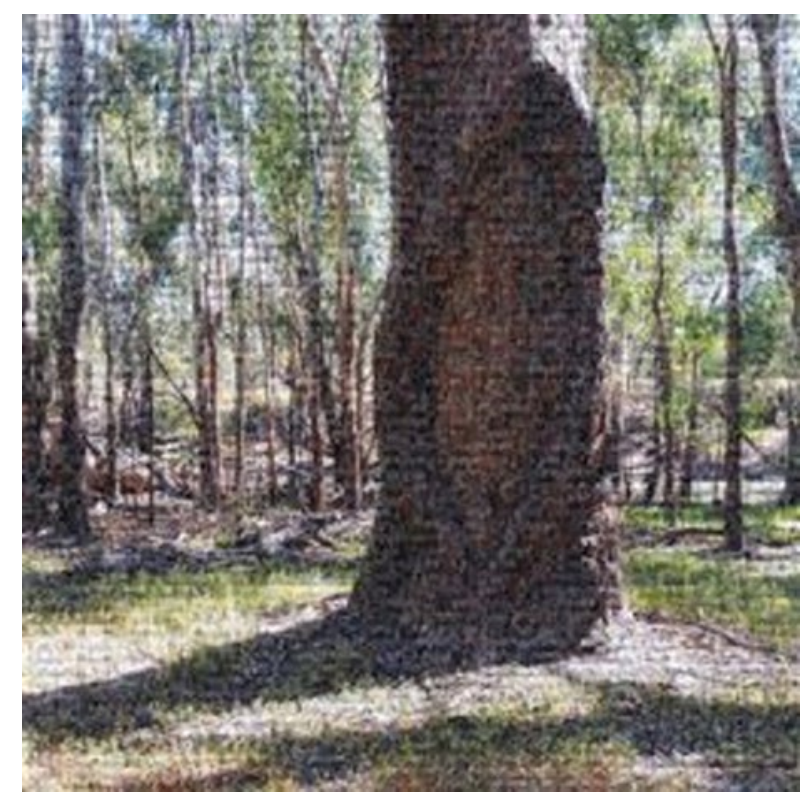

The photograph of the scarred tree, though, was a digitally-created mosaic made by combining all of the many other people whose face or story appeared, in some form, in the project. In presenting this image, the project sought to frame the Deniliquin community, both its history of migration, as well as its contemporary cultural diversity, as something that sits within an Indigenous history and landscape.

Accompanying this final artwork was the question: 'what's your migration story?'. By posing this question, we hoped viewers would leave the exhibition recognising themselves and their families not as some kind of uninvolved outsider to the concept of migration, but instead, as (privileged) participants in a long history of migration. Indeed, by foregrounding Indigenous presence and ownership, the project sought to frame all non-

\footnotetext{
${ }^{4}$ Image 7: Scarred Tree Mosaic
} 
Aboriginal people as migrants, and to use this lens as a more inclusive, compassionate and productive framework for thinking and decision-making into the future.

\section{Documentary Theatre Script/Performance}

The primary intention of the documentary theatre script was to establish a juxtaposition between the ideas and narratives of the far-right, on the one hand, and the stories of a local Aboriginal Elder (Jeanette) and a Muslim refugee (Salah), on the other. The local stories, which are detailed further below, were collected through recorded interviews. In order to capture the ideas of the far-right in the script, we selected Pauline Hanson's 2016 Senate speech, extracting segments which epitomised the narratives and assumptions highlighted above. Also included were snippets from the Pastoral Times, which were often used in contrast to the personal stories and reflections of the local Aboriginal Elder. Each of these roles - Jeanette, Salah, Hanson and the Pastoral Times - were played by community volunteers in a performance (rehearsed reading) which was held on Harmony Day in 2017.

By juxtaposing Hanson's words with the stories and perspectives of a Muslim refugee, the script did, on one level, what numerous creative and theatre works have done - to challenge and contrast anti-immigration and anti-refugee assumptions or ideas with the actual stories and experiences of migrants and refugees (Wake, 2013). For example, Hanson (2016) argues:

radicalisation is happening on our streets, in our suburbs and mosques. Yet, our leaders continue to tell us to be tolerant and embrace the good Muslims. But how should we tell the difference? There is no sign saying "good Muslim" or "bad Muslim". How many lives will be lost or destroyed trying to determine who is good and who is bad?

This simplistic sentiment - that Australians are obviously good, and Muslims, by and large, not, or even if they are good, cannot be treated as such because it is too hard to distinguish them from the baddies - is nuanced by Salah, the Iraqi refugee, who recounts his own asylum journey. Salah's story subverts the simplistic good-bad binary that Hanson feels justified in pursuing. In discussing his time in an Australian detention centre, Salah (2016) notes his distress and confusion with the Australian guards: 'When you're in the detention centre you think Australian people are no good. If we asked questions, they'd get angry with you and hit anyone who spoke to them. Push you, tell you to go! Australians, we thought, are crazy people'. In another example, Hanson (2016) argues that, in the Muslim community, 'antisocial behaviour is rampant, fuelled by hyper-masculine and misogynist culture'. At the same time, Salah (2016) tells the story of his son who, upon completion of high school, chose to study nursing at university.

Importantly, though, this playscript sought not just to question the claims of anti-immigration politics, but to challenge the assumptive foundations upon which they are built. It does this by contextualising Hanson's comments with those of Jeanette, a local Aboriginal Elder. Hanson, for example, stridently demands that new migrants learn, respect and adapt to the pre-existing culture of the place to which they have travelled: 


\begin{abstract}
Australia had a national identity before Federation, and it had nothing to do with diversity and everything to do with belonging. Tolerance has to be shown by those who come to this country for a new way of life. If you are not prepared to become Australian, obey our laws, respect our culture and way of life, then I suggest you go back to where you came from. If it would be any help, I will take you to the airport and wave you goodbye with sincere best wishes (Hanson, 2016).
\end{abstract}

What is of particular note, however, is how Hanson and her allies never acknowledge that early British migrants never engaged in such respect and adaptation. As Jeanette notes, 'it's always disconcerting to me to hear people talking about "newcomers"' (Crew, 2016). So, whilst Hanson claims that 'newcomers' need to show tolerance and adapt to a new way of life, Jeanette responds by noting: 'well, you didn't learn our language, or respect our culture, values or laws when you came' (Crew, 2016).

Hanson (2016) also argues that 'governments, both state and federal, have a duty of care to the Australian people' and that they should 'clean up your own backyard before flooding our country with more people who are going to be a drain on our society'. The play script, however, sought to disrupt this claim, deconstructing the so-called Australian people she talks of, as well as questioning who exactly is or has done the 'flooding' and 'draining' in our society. Are, for example, those who have been 'flooded' and 'drained' the local Aboriginal people who, as Jeanette highlights, remain 'the poorest people in town, the least educated, the least qualified, the sickest, the least employed' (Crew, 2016). Or, are they, as Hanson claims, the descendants of those people who migrated, in large numbers, to this country a couple of hundred years ago, and who have since drained, or claimed and stolen, so many of the goods of the country at the expense of the prior owners?

Throughout the course of her political career, Hanson has made clear her position on Aboriginal people. In her early election campaign, Hanson said she 'would be fighting for the white community, the immigrants, the Greeks, whoever, it doesn't really matter-anyone apart from the Aboriginals and the Torres Strait Islanders', and she subsequently dedicated her election victory to the 'white community' (in Moran 2002, p. 671). Moreover, during her 1998 election campaign, Hanson voiced her frustration at what she saw as the denigration of (white) Australia for its supposedly benevolent civilising of the Aboriginal population. The Aboriginal people, she argued, ought to be grateful for the process of colonisation (Moran 2002). By propagating these kinds of belittling, pejorative and dismissive narratives regarding Aboriginal people, Hanson and her many far-right allies remain emboldened in their framing of the migration and refugee issue as only a recent phenomenon in Australia. But Jeanette's concluding comment in the play dislodges this kind of unreflective arrogance:

A lot of comments about the migration stuff, and the current boat people, a lot of these negative comments are coming from what we, as Traditional Owners, consider to be newcomers to Australia, or new Australians. The white colonisers were boat people. It wasn't that long ago that your people were in the same boat, literally, so how can they sit in such judgement? (Crew, 2016) 


\section{Conclusion}

In attempting to reframe the migration and refugee debate in Australia through the foregrounding of Indigenous perspectives, the Stories of Hope and Migration project makes no claim to having presented any new or original content. Indigenous people, in numerous ways, have long articulated the hypocrisy of settler narratives. What this project did seek to do, however, was to apply the story-based strategy framework to this complex and contentious issue, and more importantly, to adapt and develop the framework so as to allow for greater engagement and resonance with the targeted local community.

This primary adaptation came in the form, style and length of the stories or narratives that were presented. For Reinsborough and Canning (2010), activists, having identified the narratives and assumptions that they are up against, need to build a compelling counternarrative which, ideally, involves (what they see as) the five key elements of storytelling: 'conflict, characters, imagery, foreshadowing, and assumptions' (pp.38-40). Interestingly, though, the focus of story-based strategy, or at least the practical applications of it they discuss, tends to emphasise the importance of encapsulating any such compelling narrative in the short form of what they call a meme - catchy slogans, images, phrases and symbols which 'can act as capsules for stories to spread virally through cultures' (Reinsborough and Canning 2010: p. 33). Whilst Reinsborough and Canning provide a range of examples where memes have indeed had great impact, there remains a tension between a strategy which, on the one hand, focuses on the sharing of compelling stories, and on the other, zeroes in on reducing these narratives into short and catchy messages. Does, for example, a decision to rely upon such catchy slogans and messages offer an advantage to power-holders with media skills and substantial resources? Does the focus on creating and distributing slogans and messages strip out the necessary nuance and complexity of stories, particularly when dealing with entrenched issues and hostile audiences?

The key point here, perhaps, is that practitioners of story-based strategy need to identify the scope of change they seek, and then adjust or adapt the style, form and length of their story strategy accordingly. In the Stories of Hope and Migration project, where we were confronting the entrenched, complex and socio-historically embedded issue of migration in Australia, a catchy message or slogan was not, in itself, sufficient for generating the engagement of those currently hostile or uninterested. Whilst the exhibition did conclude with the meme-like question, 'what's your migration story?', it only resonated as a result of the more complex narratives that were told and depicted before and around it. In this sense, the meme became not the primary result or tool of the project, but a complementary one. Further, it was a tool that could only be built from, and combined with, long, complex and nuanced stories that sought not to reduce, but to expand the ideas and vocabulary with which this contentious issue was engaged and discussed.

In sharing these stories around the issues of migration and refugees, we thought closely about which stories could/should be told, as well as the way in which these stories could/should be presented. In particular, we considered how best to scrutinise and challenge the far-right position. In some ways, the decision to use Hanson's speech as a cornerstone for criticism felt 
problematic and simplistic. Opponents of One Nation, and far-right populism in general, have long mocked the party, its leader and its damaging politics. Pauline Panstdown, for example a character created by Simon Hunt - satirised Hanson with his songs 'I Don't Like It' and 'Back Door Man'. By splicing together various spoken words from Hanson, Hunt delivered lyrics like 'Please explain, why can't my blood be coloured white, I should talk to some medical doctors, coloured blood is just not right'. These songs were an important salve and much needed reminder that whilst the political process could not only throw up someone like Hanson, but actually have them elected, we did have people in our community who saw the ridiculous absurdity - and could mock and make us laugh at their bigotry.

At the same time, however, Hunt's songs were never intended to engage with or bring on board those who were aligning themselves with Hanson's politics. To use SBS terminology, it was a story of the battle approach which, through humour, sought to invigorate and activate already-existing supporters. I note this kind of dynamic because at the time when the Stories of Hope and Migration project was initiated, much media commentary noted a kind of elitism on behalf of those who were critical of the far-right. These people were, it was increasingly argued, seemingly content with their so-called progressive political bubble and in-jokes, but not properly or respectfully engaging with or understanding the increasing amount of support for this kind of politics that was occurring outside their general sphere of engagement.

Whilst important questions remain as to whether, and if so, how, racist politics should be respectfully engaged with, this project acknowledged that a more conducive way of prompting discussion on this topic was possibly not to ridicule something that people might believe or assume, but to genuinely hold that belief or assumption up to critical scrutiny. To this end, Hanson was not mocked or presented melodramatically. Rather, her words, representative of the 'stock narratives' we hear on refugees and migration, were placed alongside the often 'concealed stories' (Bell,2019) of an Iraqi refugee and an Aboriginal Elder from the local community. In this way, audience members were offered the chance to assess both for their legitimacy and credibility.

At the same time, at the project's conclusion, one of the first comments received was that, given the attending audience on the night, the project was 'preaching to the converted'. If this was the case, then the project didn't succeed in fulfilling the battle of the story approach. And yet, as the group reflected on the viewer's comment, a more nuanced and encouraging analysis was offered by one of the volunteer performers. Her argument was that the project was successful in moving beyond the so-called converted, because it was able, through the participation of various community members/groups, to draw in audience members who would otherwise have never attended such an event. According to this project participant, the attendance of her parents-in-law was powerful proof of the potential for such a process to engage community members who were, at best, apathetic to the issues raised in the performance. Their attendance was, of course, secured only through the involvement of their daughter-in-law as a performer, but it was a community engagement model, she argued, that was replicated many times over for the other volunteer performers who had taken part. 
By integrating the SBS framework with a community arts approach, this project was able to engage a variety of community members with a range of stories that undercut many of the dominant assumptions held regarding migrants and refugees in Australia. In doing this, our project was not, of course, ever going to single-handedly shift the foundations of the refugee debate whilst simultaneously re-working the power asymmetry between Aboriginal and nonAboriginal people in Australia. But it did work to spark constructive community conversations that operated on more historically-aware foundations, and in so doing, strove to dry up the wellspring from which far-right politics too easily emerges.

\section{Acknowledgements}

I thank Jeanette Crew, David Crew, Jennifer Townsend, Brian Martin, Kate Butler, Karen Wilson and two anonymous reviewers for valuable feedback on this article.

The Stories of Hope and Migration project was carried out by Yarkuwa Indigenous Knowledge Centre and was funded by Arts NSW and Multicultural NSW.

\section{References}

Aldorki, S. 2016, Interview: Stories of Hope and Migration.

Aly, W. 2019, The most dishonest thing would be to say that I'm shocked', Sydney Morning Herald, 16 March, 2019. Available at: https://www.smh.com.au/world/oceania/themost-dishonest-thing-would-be-to-say-that-i-m-shocked-20190316-p514q2.html.

Anning, F. 2018, 'Full text: Senator Fraser Anning's maiden speech', SBS News, 15 August 2018. Available at: https://www.sbs.com.au/news/full-text-senator-fraser-anning-smaiden-speech.

Barlow, K. 2014, 'Scott Morrison says 157 Tamil asylum seekers are 'economic migrants' not in danger of persecution in India, calls Labor and Greens 'surrender monkeys", $A B C$ News, 28 July 2014. Available at: https://www.abc.net.au/news/2014-07-28/consularstaff-begin-processing-of-tamil-asylum-seekers/5627732.

Barton, G. 2019, Christchurch: The 'how' is explainable. The 'why' is harder to digest. Sydney Morning Herald, 17 March 2019. Available at: https://www.smh.com.au/world/oceania/christchurch-the-how-is-explainable-the-whyis-harder-to-digest-20190317-p514v1.html.

Bell, L. A. 2019, Storytelling for Social Justice: Connecting Narrative and the Arts in Antiracist Teaching, $2^{\text {nd }}$ ed. Routledge, London. https://doi.org/10.4324/9781315101040

Crew, J. 2016, Interview: Stories of Hope and Migration.

Davis, J. E. 2002, Stories of Change: Narrative and Social Movements, State University of New York Press, Albany.

Dingle, S. 2014, Tony Abbott names white settlement as Australia's 'defining moment', remark draws Indigenous ire, $A B C$ News, 30 August 2014. Available at: https://www.abc.net.au/news/2014-08-30/pm-comment-on-defining-moment-angersindigenous-groups/5707926.

Green, M.C., Strange, J.J. and Brock, T.C. 2002, Narrative Impact: Social and Cognitive Foundations, Lawrence Erlbaum, Mahwah, NJ. https://doi.org/10.4324/9781410606648 
The Guardian 2018, 'South Africa demands Peter Dutton retract "offensive" statement on white farmer plight', The Guardian, 16 March 2018, Available at:

https://www.theguardian.com/australia-news/2018/mar/16/south-africa-peter-duttonoffensive-statement-white-farmers.

Hanson, P. 1996, 'Pauline Hanson's 1996 maiden speech to parliament: Full transcript', Sydney Morning Herald, 15 September 2016, Available at:

https://www.smh.com.au/politics/federal/pauline-hansons-1996-maiden-speech-toparliament-full-transcript-20160915-grgjv3.html.

Hanson, P. 2016, 'Transcript: Pauline Hanson's 2016 maiden speech to the Senate', $A B C$ News, 15 September 2016. Available at: https://www.abc.net.au/news/2016-0915/pauline-hanson-maiden-speech-2016/7847136.

Hawley, S. 2013, 'Rudd to focus on economic refugees during visit to Indonesia', $A B C A M$, 29 June 2013, Available at: https://www.abc.net.au/am/content/2013/s3792377.htm.

Henderson, A. 2014, 'Prime Minister Tony Abbott describes Sydney as "nothing but bush" before First Fleet arrived in 1788', ABC News, 14 November 2014. Available at: https://www.abc.net.au/news/2014-11-14/abbot-describes-1778-australia-as-nothingbut-bush/5892608.

Hone, J. A. 1974, Peppin, George Hall. Available at: http://adb.anu.edu.au/biography/peppingeorge-hall-4388.

Howard, J. 2001, Election Speeches. Available at: https://electionspeeches.moadoph.gov.au/speeches/2001-john-howard.

Hunter, F. and Preiss, B. 2018, 'Victorians scared to go to restaurants at night because of street gang violence: Peter Dutton', Sydney Morning Herald, 3 January 2018. Available at: https://www.smh.com.au/politics/federal/victorians-scared-to-go-to-restaurants-atnight-because-of-street-gang-violence-peter-dutton-20180103-h0cvu4.html.

Karp, P. 2018, "'OK to be white": Australian government senators condemn "anti-white racism"', The Guardian, 15 October 2018. Available at:

https:/www.theguardian.com/australia-news/2018/oct/15/ok-to-be-white-australiangovernment-senators-condemn-anti-white-racism.

Mayer, F. 2014, Narrative Politics: Stories and Collective Action, Oxford University Press, New York. https://doi.org/10.1093/acprof:oso/9780199324460.001.0001

Moran, A. 2002, 'The psychodynamics of Australian settler-nationalism: Assimilating or reconciling with the Aborigines?' Political Psychology vol. 23, no.4, pp. 667-701. https://doi.org/10.1111/0162-895x.00303

Pastoral Times 1878, [No title] 26 October, Deniliquin.

Pastoral Times 1882, 'Reminiscences of Old Deniliquin', Pastoral Times, 14 October, Deniliquin.

Pastoral Times 1897, 'Chinese Immigration', Pastoral Times, 23 October, Deniliquin.

Refugee Council of Australia 2016, Economic migrants or refugees? Available at: https://www.refugeecouncil.org.au/economic-migrant-or-refugee/.

Reinsborough, P. and Canning, D. 2010, Re:Imagining Change: How to Use Story-Based Strategy to Win Campaigns, Build Movements and Change The World, PM Press, Oakland, CA. 
Saffran, J. 2017, Depends What You Mean by Extremist: Going Rogue with Australian Deplorables, Penguin, Melbourne.

Sas, N. and Gerathy, S. 2018, 'NSW Labor leader Luke Foley apologises for "white flight" comments as Pauline Hanson backs him in', $A B C$ News, 24 May 2018. Available at: https://www.abc.net.au/news/2018-05-24/foley-apologises-for-white-flightcomments/9796548.

SBS News 2019, 'Migration debate wrong tone in tough week', SBS News, 22 March 2019. Available at: https://www.sbs.com.au/news/migration-debate-wrong-tone-in-toughweek.

Solinger, R., Fox, M. and Irani, K. (eds.) 2008, Telling Stories to Change the World: Global Voices on the Power of Narrative to Build Community and Make Social Justice Claims, Routledge, London. https://doi.org/10.4324/9780203928066

Trist, J. 2011, 'Silent feet', Pastoral Times, 14 January 2011. Deniliquin.

VanDeCarr, P. 2015, Storytelling and Social Change, $2^{\text {nd }}$ ed., Working Narratives. https://workingnarratives.org/wp-content/uploads/2016/02/story-guide-secondedition.pdf

Visentin, L. 2019, 'Michael Daley claims foreigners taking young people's jobs', Sydney Morning Herald, 18 March 2019. Available at: https://www.smh.com.au/nsw-election2019/michael-daley-claims-foreigners-taking-young-people-s-jobs-20190318p51591.html.

Wake, C. 2013, 'To witness mimesis: the politics, ethics, and aesthetics of testimonial theatre in Through the Wire', Modern Drama, vol. 56, no.1, pp. 102-125. https://doi.org/10.3138/md.2012-0465

Zingaro, L. 2016, Speaking Out: Storytelling for Social Change, Routledge, London. https://doi.org/10.4324/9781315419930 